\title{
PENGEMBANGAN MODUL MATEMATIKA SMP BERBASIS PENDEKATAN KONSTRUKTIVISME
}

\author{
Jazim $^{1)}$, Rahmad Bustanul Anwar ${ }^{2)}$, Dwi Rahmawati ${ }^{3)}$ \\ 1), 2), 3) Pendidikan Matematika, FKIP Univ. Muhammadiyah Metro \\ jazimahmad60@yahoo.com ${ }^{1)}$,rarachmadia@gmail.com ${ }^{2)}$, \\ dwirahmawati1083@gmail.com ${ }^{3)}$
}

\begin{abstract}
The aim of this study was to develop a module of mathematics at the junior high school level class VIII. It is based on the observation of books or teaching materials used in schools is an informative and not involve students in the learning process. This study develops a mathematical module VIII Junior High School class-based constructivism. Constructivism approach chosen by reason will lead students in finding and independently formulate a mathematical concept. This type of research is the development of research (Research and Development), which is intended to develop modules Junior High School math class VIIIbased constructivism. This research subject is class VIII student at Junior High School 2 Metro, Junior High School 4 Metro and Junior High School 6 Metro. When the study for two years in which the first year to implement the development of modules and the second year of implementing use of modules developed and seen the results of student learning. Implementation of the research in the first year has been implemented which reached the stage of expert validation and testing of the small scale of the development of junior high school math module VIII class-based constructivism.
\end{abstract}

Keywords: Module, Junior High School Math, Constructivism approach.

\section{PENDAHULUAN}

Matematika merupakan salah satu ilmu yang mendukung dalam perkembangan IPTEK pada kemajuan zaman saat ini. Dengan matematika pola pikir seseorang akan menjadi lebih logis dan terstruktur. Sehingga perlu adanya penguatan dalam penanaman konsep matematika yang baik pada siswa yang mempelajari matematika. Depdiknas (2004) bahwa tujuan pendidikan matematika tingkat nasional adalah memberikan bekal matematika kepada siswa sehingga mampu memanfaatkannya dalam menghadapi berbagai situasi, termasuk dalam menghadapi masalah sehari-hari. Selain itu prinsip pembelajaran matematika di sekolah dalam NCTM (2000: 11) menekankan siswa harus belajar matematika dengan pemahaman, aktif membangun pengetahuan baru dari pengalaman dan pengetahuan. Pembelajaran matematika yang efektif memerlukan pemahaman siswa dari apa yang mereka ketahui dan yang perlu mereka pelajari kemudian memberikan tantangan dan dukungan kepada mereka untuk belajar lebih lanjut. Tassell, J. L., dkk. (2012) menjelaskan bahwa penerapan matematika dan ilmu pengetahuan alam melalui pengalaman nyata siswa sangat penting pada proses pembelajaran.

Matematika SMP masih berorientasi dengan matematika realistik, dimana dalam materi matematika SMP masih berifat konkrit dan belum bersifat abstrak. Menurut Piaget (Hudojo,1990: 35-37) perkembangan intelektual anak dapat dibagi dalam empat periode, yaitu : 1) Periode sensori motorik pada usia 0-2 
tahun; 2) Periode pra-operasional pada usia 2-7 tahun ; 3) Periode operasi konkrit pada usia 7-11/12 tahun; 4) Periode operasi formal pada usia 11 atau 12 tahun ke atas. Berdasarkan pembagian periode perkembangan intelektual anak oleh Piaget, siswa SMP berada pada periode operasi konkrit dan mulai memasuki periode operasi formal. Periode operasi konkrit merupakan permulaan berpikir rasional dan siswa memiliki operasi-operasi logis yang dapat diterapkan pada masalah konkrit. Kemampuan siswa operasi konkrit berbeda dengan siswa operasi formal. Siswa pada periode konkrit dan formal keduanya sudah dapat menyelesaikan masalah klasifikasi, namun pada periode konkrit siswa belum mampu menyelesaikan masalah klasifikasi tanpa adanya data konkrit.

Berdasarkan

pengamatan peneliti bahan ajar yang ada seperti lembar kerja (worksheet) dan buku yang tersedia dalam menjelaskan konsep ataupun teori hanya bersifat informasi saja, sehingga belum mampu merangsang siswa untuk mengembangkan kemampuan berpikir kritis, daya analitis, dan kemampuan pemecahan masalah. Menurut Sato (2007) yang berdasarkan pengalamannya dalam kegiatan IMSTEP-JICA di Indonesia, ia mengemukakan bahwa sebagian besar guru di Indonesia masih menerapkan metode konvensional, pertanyaan yang diajukan guru kepada siswa masih berupa pertanyaan sederhana, materi buku teksyang digunakan lebih cocok bagi tingkat menengah dari kelompok atas siswa, guru cenderung mengelola pelajaran bagi tingkat menengah dari kelompok atas siswa, dan siswa yang mampu memetik ilmu hanyalah mereka yang dalam kelompok menengah. Metode konvesional yang menganut aliran behaviorisme tersebut hendaknya diubah menuju pada aliran konstruktivisme. Oleh karena itu dalam penelitian ini akan dikembangkan modul matematika SMP berbasis konstruktivisme.

Menurut Major,dkk. (2012) konstruktivisme merupakan teori pembelajaran yang mendeskripsikan proses dari konstruksi pengetahuan. Konstruksi pengetahuan merupakan suatu proses aktif, bukan pasif. Konstruktivis mempercayai bahwa pengetahuan tidak hanya tersimpan dalam pikiran siswa, melainkan hal ini harus dikonstruksi oleh siswa melalui keterlibatan aktif dalam proses pembelajaran. Sedangkan Ann-Sofi Röj-Lindberg (2001) menyatakan dalam proses pembelajaran yang aktif mengharuskan siswa secara aktif mengkonstruk pemahamannya terhadap konsep matematis. Tujuan dari proses pengajaran dalam matematika harus menentukan suatu kultur pembelajaran yang mempromosikan pembelajaran yang cerdas dan pemahaman konsep matematis yang mendalam.

Menurut Sagala (2009: 88)

"Konstruktivisme (constructivisme) merupakan landasan berpikir (filosofis) pendekatan konstektual, yaitu pengetahuan dibangun sedikit demi sedikit, yang hasilnya diperluas melalui konteks yang terbatas (sempit) dan tidak dengan tiba-tiba. Pengetahuan bukanlah seperangkat fakta-fakta, konsep atau kaidah yang siap untuk diambil dan diingat. Tetapi manusia harus mengkonstruksi pengetahuan itu dan memberi makna melalui pengalaman nyata".Salah satu konsep dasar pendekatan konstruktivisme dalam belajar adalah adanya interaksi sosial individu dengan lingkungannya. Dalam pembelajaran konstruktivisme, penambahan pengetahuan baru dilakukan oleh siswa sendiri. Pengembangan pengetahuan dapat 
dilakukan dengan pemberian rangsangan berupa masalah-masalah dari dunia nyata yang relevan dengan kebutuhan siswa, untuk dibahas dan dicari jalan keluarnya. Pemberian masalah dimaksudkan untuk merangsang siswa agar berpendapat dan berpikir kritis ketika kepada mereka dihadapkan fakta-fakta baru (Mudjiman (2008: 25)).

dipilih $\begin{array}{r}\text { Pendekatan } \\ \text { dengan alasan untuk }\end{array}$ mengarahkan siswa dalam menemukan dan merumuskan secara mandiri suatu konsep matematika. Pendekatan konstuktivisme merupakan salah satu pendekatan pembelajaran yang menekankan pada pola pembangunan pengetahuan melalui pengaitan/konstruksi antara pengetahuan yang telah dimiliki dengan pengetahuan yang baru. Berdasar alasan tersebut penelitian ini mencoba mengembangkan modul matematika SMP kelas VIII berbasis kostruktivisme.

\section{METODE PENELITIAN}

Jenis penelitian ini adalah pengembangan (Research and Development) yang dimaksudkan untuk mengembangkan modul matematika SMP berbasis konstruktivisme. Penelitian ini menggunakan data kualitatif dan kuantitatif. Data kualitatif digunakan untuk memperoleh gambaran yang lengkap mengenai kelayakan modul matematika SMP yang dikembangkan dan divalidasi oleh para ahli. Data kuantitatif digunakan untuk melihat dampak dari penggunaan modul matematika SMP terhadap hasil belajar siswa setelah melaksanakan pembelajaran di kelas.Subjek dalam penelitian ini adalah siswa kelas VIII SMP Negeri di Kota Metro yang meliputi SMP N 2 Metro, SMP N 4 Metro dan SMP N 6 Metro. Waktu pelaksanaan penelitian direncanakan akan berlangsung selama dua tahun, yakni: tahun pertama, meliputi studi pendahuluan dan pengembangan, dan tahun kedua, melakukan desiminasi, untuk melihat dampak atau hasil dari penggunaan modul yang dikembangkan pada penelitian ini.

\section{HASIL PENELITIAN DAN PEMBAHASAN}

Hasil yang dicapaian pada tahun pertama dari penelitian ini adalah:

\section{Tahap I. Studi Pendahuluan}

Studi pendahuluan yang dilaksanakan dalam penelitian ini meliputi studi literatur dan studi lapangan. Studi literatur dilakukan dengan mengkaji materi matematika kelas VIII dari berbagai refrensi diantaranya Silabus Matematika Kelas VIII, Buku Matematika SMP Kelas VIII, Buku Matematika SMP Kelas VIII Kurikulum 2013, Materi terbitan PPPPTK Matematika. Sedangkan studi lapangan dilaksanakan di SMP N 2 Metro, SMP N 4 Metro dan SMP N 6 Metro. Studi lapangan lebih banyak wawancara dengan guru matematika terkait dengan proses pembelajaran yang dilaksanakan dan buku-buku matematika yang digunakan. Pelaksanaan studi lapangan terkendala dengan pengambilan data melalui observasi dari proses pembelajaran. Hal tersebut terkendala dengan pelaksanaan observasi yang bersamaan dengan ujian akhir semester di sekolah.

\section{Tahap II. Perencanaan}

Berdasar hasil studi pendahuluan, tahap perencanaan ini dengan melakukan penyusunan produk awal atau draf awal modul matematika SMP Kelas VIII berbasis konstruktivisme semester ganjil. Materi 
penyusunan modul tersebut mengacu pada hasil studi literatur yang dilakukan dan mengikuti komponen-komponen yang harus muncul pada modul berupa judul, petunjuk umum, materi dan evaluasi. Hasil penyusunan draf awal modul matematika SMP Kelas VIII berbasis konstruktivisme semester ganjil berisi 6 bab materi yaitu Sistem Koordinat, Operasi Aljabar, Fungsi, Persamaan Garis Lurus, Teorema Phytagoras dan Statistika.

\section{Tahap III. Pengembangan}

Tahap pengembangan pada penelitian ini dilakukan dengan melakukan ujicoba terbatas yang melibatkan dua orang guru SMP. Tahap ini bertujuan untuk melihat kesesuaian materi di dalam modul dengan materi yang disampaikan di sekolah. Selain itu juga bertujuan untuk melihat konten materi di dalam modul dengan konsep konstruktivisme yang bercirikan berisi materi kontekstual dan pembelajaran berpusat pada siswa.

\section{Tahap IV. Validasi}

Validasi dalam penelitian ini dilakukan meliputi dua hal, yaitu validasi instrumen dan validasi draf modul. Pelaksanaan validasi draf modul melibatkan tiga orang ahli. Pertama Drs. Sukoriyanto, M.Si. dari Universitas Negeri Malang dengan bidang keahlian Matematika. Kedua, Dra. Nur Hanurawati, M.Pd. dari Universitas Negeri Lampung dengan bidang keahlian Pembelajaran Matematika. Ketiga Dra. Sutrisni Andayani, M.Pd. dari Universitas Muhammadiyah Metro dengan bidang keahlian Pembelajaran Matematika. Proses pelaksanaan validasi sampai saat ini masih berlangsung.

Setelah modul dinyatakan valid oleh para ahli, modul diujicoba pada skala kecil dalam proses pembelajaran matematika di kelas VIII SMP N 4
Metro. Dari hasil ujicoba dilakukan revisi berdasar kekurangan yang diperoleh dari proses ujicoba. Tahap berikutnya yang akan dilakukan adalah uji lapangan penggunaan modul pada subjek yang telah ditentukan dalam proses pembelajaran. Setelah pembelajaran matematika dengan menggunakan modul matematika SMP kelas VIII berbasis konstruktivisme selesai, diakhiri dengan pemberian tes akhir. Hasil tes tersebut digunakan sebagai acuan untuk melihat apakah penggunakan modul hasil pengembangan ini memberikan hasil belajar yang baik.

\section{HASIL PENELITIAN DAN PEMBAHASAN}

Berdasar hasil pelaksanaan penelitian, ada beberapa hal yang perlu dilaksanakan dalam proses pengembangan modul, yaitu: (1) Melakukan revisi terhadap saran dari validasi ahli. Setelah draf modul telah dinyatakan valid oleh para validator. Tahap berikutnya adalah melakukan uji lapangan pada subjek yang ditentukan dengan menggunakan modul dalam proses pembelajaran dengan menggunakan metode pembelajaran yang telah ditentukan. (2) Setelah pembelajaran matematika dengan menggunakan modul matematika SMP kelas VIII berbasis konstruktivisme selesai, diakhiri dengan pemberian tes akhir. Hasil tes tersebut digunakan sebagai acuan untuk melihat apakah penggunakan modul hasil pengembangan ini memberikan hasil belajar yang baik.

\section{KESIMPULAN DAN SARAN}

Pelaksanaan penelitian ini telah sampai pada tahap validasi ahli terhadap pengembangan modul matematika SMP kelas VIII berbasis konstruktivisme. Pengembangan modul dalam penelitian 
ini mengacu pada penerapan kurikulum 2013 dengan mengacu silabus kurikulum 2013 dan merujuk bukubuku matematika SMP kelas VIII yang digunakan dalam pelaksanaan pembelajaran kurikulum 2013. Penelitian ini terbatas pada pengambangan modul SMP kelas VIII berbasis konstruktivisme fokus pada semester ganjil. Sedangkan untuk semester genap belum dilakukan pengembangan, sehingga dapat dilakukan penelitian oleh penelitian berikutnya.

Saran dalam penelitian ini adalah penelitian ini terbatas pada pengambangan modul SMP kelas VIII berbasis konstruktivisme fokus pada semester ganjil. Sedangkan untuk semester genap belum dilakukan pengembangan, sehingga dapat dilakukan penelitian oleh penelitian berikutnya.

\section{DAFTAR PUSTAKA}

Ann-Sofi Röj-Lindberg. 2001. Active Learning of Mathematics. Experiential Learning for the Third Millenium. Vol. 2, 159168.

(Online), http://www.vasa.abo.fi/users/ar oj/Active\%20learning\%20of\% 20mathematics.pdf., diakses, 13 Maret 2015.

Major, T. E., Mangope, B. 2012. The Constructivist Theory in Mathematics: The Case of Botswana Primary Schools, (Online), (http://irssh.com/yahoo_site_ad min/assets/docs/15_IRSSH-155V3N2.202200518.pdf), diakses 17 Januari 2015.

Mudjiman, Haris. 2008. Belajar Mandiri. Surakarta: UNS Pers.
NCTM. 2000. Principles and Standars for School Mathematics. United States of America: The National Council of Teachers of Mathematics, Inc.

Sagala, Syaiful. 2009. Konsep dan Makna Pembelajaran. Bandung: Albabeta.

Sato, Manabu. 2007. Tantangan yang Harus Dihadapi Guru. Dalam Bacaan Rujukan untuk Lesson Study: Sisttems (Strengthening In-service Training of Mathematics and Science Education at Junior Secondary Level). Dirjen PMPTKDepdiknas dan JICA.

Tassell, J., L., McDaniel, K., Johnson, H., Norman, A., Pankratz, R., \& Tyler, R. (2012). Explore Performance in Mathematics and Science: Why are Middle School Students Unprepared for Success in Mathematics and Science?. International Journal of Innovation in Science and Mathematics Education, 20(1), 1-23, 2012. (Online), (http://openjournals.library.usyd. edu.au/index.php/CAL/issue/vie w/474), diakses 6 November 2015. 